\title{
IRF6 wt Allele
}

National Cancer Institute

\section{Source}

National Cancer Institute. IRF6 wt Allele. NCI Thesaurus. Code C75617.

Human IRF6 wild-type allele is located within 1q32.3-q41 and is approximately $18 \mathrm{~kb}$ in length. This allele, which encodes interferon regulatory factor 6 protein, is involved in the modulation of transcription. Mutation of the gene is associated with van der Woude syndrome and popliteal pterygium syndrome and genetic variation is a factor in orofacial cleft type 6. 